\title{
Trypanosoma cruzi: Establishment of Permeable Cells for RNA Processing Analysis with Drugs
}

\author{
DL Ambrósio ${ }^{++}$, CF Barbosa, VF Vianna ${ }^{+++}$, RMB Cicarelli $^{+}$ \\ Departamento de Ciências Biológicas, Faculdade de Ciências Farmacêuticas, Unesp, Rod. Araraquara-Jaú km 1, \\ 14801-902 Araraquara, SP, Brasil
}

\begin{abstract}
Pre-mRNA maturation in trypanosomatids occurs through a process called trans-splicing which involves excision of introns and union of exons in two independent transcripts. For the first time, we present the standardization of Trypanosoma cruzi permeable cells ( $Y$ strain) as a model for trans-splicing study of mRNAs in trypanosomes, following by RNase protection reaction, which localizes the SL exon and intron. This trans-splicing reaction in vitro was also used to analyze the influence of $\mathrm{NFOH}-121$, a nitrofurazone-derivative, on this mechanism. The results suggested that the prodrug affects the RNA processing in these parasites, but the trans-splicing reaction still occurred.
\end{abstract}

Key words: trans-splicing - Trypanosoma cruzi - NFOH-121 (hydroxymethylnitrofurazone)

In the process of pre-mRNA maturation, known as splicing, the introns (non-coding regions of polypeptides) are removed from primary transcripts and the exons (coding regions) joined to form a contiguous sequence specifying a functional polypeptide. It was observed that the process is dependent on ribonucleoproteins, small molecules of RNA binding proteins with different forms and sizes, assembling a macromolecular complex called the spliceosome, where the maturation reaction takes place (Leningher et al. 1995). In trypanosomes, all the RNAs are processed by a mechanism different from that in mammals (cis-splicing) called trans-splicing, a process that involves the union of the exons in two independent transcripts. However, in recent studies it was observed that cis-splicing can also occur in the gene PAP (poly-A polymerase) of Trypanosoma brucei and T. cruzi, suggesting that both trans and cis-splicing, occur in these parasites, with a predominance of trans-splicing (Mair et al. 2000).

The SL RNA or miniexon is a primary transcript synthesized independently of pre-mRNA and trans-spliced in all nuclear mRNA. The majority of mRNAs is synthesized as polycistronic precursors (Agabian 1990). T. brucei SL RNA contains an unusual cap structure consisting of 7-methylguanosine linked to four modified nucleosides. This modification of trypanosomatid SL sequence might be required for the function of the SL RNA in trans-splic-

Financial support: Fundação de Amparo à Pesquisa do Estado de São Paulo, procs 99/11393-4 and 00/02871-9, PADC/FCFUnesp (proc. 2002/12-1)

${ }^{+}$Corresponding author. Fax. +55-16-33016940. E-mail: cicarell@fcfar.unesp.br

${ }^{++}$Supported by Pibic/CNPq

${ }^{+++}$Supported by Fapesp

Received 5 April 2004

Accepted 18 August 2004 ing and the mRNA during translation (Ullu \& Tschudi 1991).

Our preliminary results of trans-splicing in vitro with nuclear extracts of T. cruzi epimastigote forms and $\alpha$ tubulina as a synthetic pre-mRNA demonstrated that the processing of pre-mRNA could also occur without living cells, but the use of this reaction as a model of transsplicing study becomes highly difficult on the reproducibility and time consuming to evaluate molecules which can intervene direct or indirectly in trans-splicing in trypanosomes (Vianna et al. 2001).

As described by Ullu and Tschudi (1990), T. brucei cells can be treated with lysolecithin that makes the parasites permeable to triphosphate and radioactive nucleotides, as well as other small molecules, and were able to synthesize the mRNAs. For confirmation of the reaction, the RNase protection using a transcript containing antisense sequence to SL RNA was used as a probe, followed by enzymatic treatment with RNases A and T1, which degraded non-hybrid mRNAs and allowed the localization of SL exon and intron, respectively.

In our experiments using T. cruzi Y strain (Silva \& Nussenzweig 1953), $1.25 \times 10^{8}$ epimastigotes forms (exponential growth phase in LIT medium and $28^{\circ} \mathrm{C}$ ) were washed and resuspended in TB $[1 \mathrm{X}]$ solution $(20 \mathrm{mM}$ KGlu, $3 \mathrm{mM} \mathrm{MgCl} 2,1 \mathrm{mM}$ DTT, $10 \mu \mathrm{g} / \mathrm{ml}$ Leupeptin) and treated with different concentrations $(25,50,100,200 \mu \mathrm{g})$ of L- $\alpha$-lysophosphatidylcholine and palmitoyl (Lysolecithin, Sigma). To initiate the transcription/trans-splicing reaction, a mixture of reagents with the following final concentrations was added: $2 \mathrm{mM}$ ATP (Gibco BRL), $1 \mathrm{mM}$ GTP(Gibco BRL), 1 mM CTP(Gibco BRL), [0,5X] TB, 0,6 $\mathrm{mg} / \mathrm{ml}$ creatine kinase (Roche), $25 \mathrm{mM}$ creatine phosphate (Sigma) and $500 \mathrm{Ci} / \mathrm{ml}\left[\alpha_{-}{ }^{32} \mathrm{P}\right]$ UTP (Amershan Biosciences). After the incubation at $28^{\circ} \mathrm{C}$, aliquots were removed at different times (time-course) and the parasites immediately lysed with Trizol (Life Technologies), the RNAs recovered after chloroform extraction, precipitated 
with isopropanol and resuspended in $50 \%$ formamide/5X SET solution ( $50 \%$ formamide, $3 \mathrm{M} \mathrm{NaCl}, 20 \mathrm{mM} \mathrm{EDTA} \mathrm{pH}$ 8.0, 0.6M Tris- $\mathrm{HCl} \mathrm{pH} 8.0$ ), followed by electrophoresis on a $10 \%$ polyacrylamide $-7 \mathrm{M}$ urea gel and revealed after 1-day exposure at $-80^{\circ} \mathrm{C}$ in autoradiography.

The reaction was incubated for different times and amounts of lysolecithin to check the best time for maximum transcription without degrading the recently formed mRNAs. Fig. 1 presents the results with T. cruzi Y strain incubated for different times $(0,5,10,20 \mathrm{~min})$, using different amounts of lysolecithin $\left(25,50,100,200 \mu \mathrm{g} / 1.25 \times 10^{8}\right.$ parasites). We observed that the production of RNAs was increased when the lysolecithin concentration was raised up $100 \mu \mathrm{g} / 1.25 \times 10^{8}$ parasites. No bands were seen with $200 \mu \mathrm{g}$ (data not shown), since a high number of pores on the membrane should promote lost of cell integrity. From these results, $100 \mu \mathrm{g}$ of lysolecithin was chosen as the optimal amount for our experiments. These findings were in accordance with those observed in T. brucei (Ullu \& Tschudi 1990).

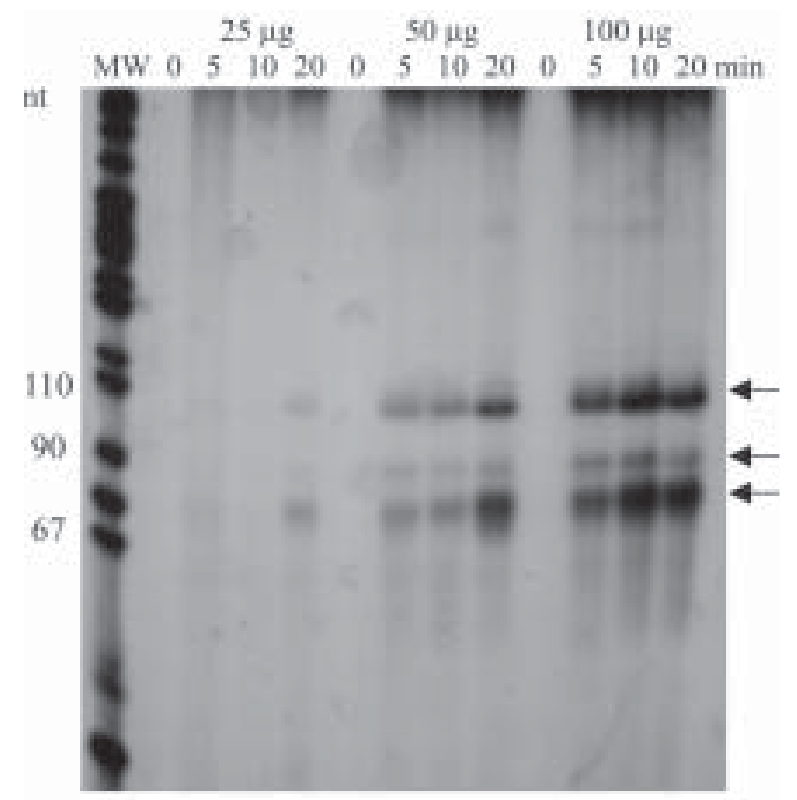

Fig 1: time-course of Trypanosoma cruzi (Y strain) permeable cells reaction using different concentrations of lysolecithin. RNAs electrophoresed on a $10 \%$ polyacrylamide - $7 \mathrm{M}$ urea gel and detected by autoradiography. Molecular weight: pBR322 digested with MspI labelled with $\left[{ }^{32} \mathrm{P}\right]-\mathrm{dCTP}$. The arrows indicate the newly synthesized RNAs.

To confirm the trans-splicing reaction, the RNase protection procedure was done using the same probe described by Ullu and Tschudi (1990) [a complementary antisense sequence to the region of the 7 to $105 \mathrm{nt}$ of SL RNA of $T$. cruzi $\mathrm{Y}$ strain (5 - CGCTATTATTGATACA GTTTCTGTACTATATTGGTACGCGAAGCTTCCAA CCCCCTCTGGCGGTTATGTTTGGGCAATTTCTTTT GACCGGGGTCG-3') cloned in pBS vector]. The linearized plasmid (EcoRI-digested) was used in a cold transcription reaction in vitro using T3 RNA polymerase (USB) and $200 \mathrm{ng}$ of antisense-SL RNA in $50 \%$ formamide/5X SET solution was incubated for $15 \mathrm{~min}$ at $80^{\circ} \mathrm{C}$, for RNA denaturation, followed by the addition of $2 \mu$ of transcription/trans-splicing reaction with permeable cells (RNAs), repeating the incubation at $80^{\circ} \mathrm{C}$ and then at $37^{\circ} \mathrm{C}$ for $16-18 \mathrm{~h}$. After the addition of the solution containing RNAses [300 mM NaCl, 10 mM Tris- $\mathrm{HCl}$ pH 7.5, 5 mM EDTA, $20 \mu \mathrm{g} / \mathrm{ml}$ RNase A (Amersham Biosciences), $5 \mathrm{U} /$ $\mathrm{ml}$ RNase T1 (Gibco BRL)], the mixture was incubated for $1 \mathrm{~h}$ on ice, which promoted single-strand RNA degradation, allowing then the localization of SL exon and intron in the preparations. The RNA hybrids were extracted with phenol/chloroform/isoamylalcohol (25:24:1, v/v), precipitated with $20 \mu \mathrm{g} / \mathrm{ml}$ glycogen and $100 \%$ ethanol (2.5 vol.) and the pellets were resuspended in formamide buffer to be electrophoresed on a $10 \%$ polyacrylamide gel - 7M urea followed by autoradiography (after exposition of 7 days at $-80^{\circ} \mathrm{C}$ ).

Fig. 2 showed the reaction carried out with T. cruzi $\mathrm{Y}$ strain permeable cells incubated for different periods of time $(5,10,20,30 \mathrm{~min}) ; 20 \mathrm{~min}$ of incubation was chosen as standard time because there was no degradation of the newly formed RNAs (Figs 1, 2). This period was longer than that described in trans-splicing reaction with T. brucei (7 min) (Ullu \& Tschudi 1990). One possible explanation for this difference of time reaction is the heterogeneity interspecies among these parasites. We also could identify the bands that represent the methylated and nonmethylated SL RNA, and the SL intron, as indicated by the symbols in the figure. According to Ullu and Tschudi (1990), methylation of the SL RNA 5' end is a general requirement for trans-splicing activity of trypanosomatid SL RNAs; the presence of a double-band (methylated and non-methylated) and SL intron in the experiment (Fig. 2, as indicated) confirms the evidence of trans-splicing reaction.

The use of S-adenosyl-L-homocysteine (Ado-Hcy) inhibits trans-splicing reaction by competitive inhibition of S-adenosyl-L-methionine (Ado-Met) mediated 5'end methylation reactions and it allows the analysis of the methylation as a rule for trans-splicing reaction. Its addition $(5 \mathrm{mM})$ in the transcription/trans-splicing reaction mix, following by RNase protection as described before, it allowed the localization of methylated-SL exon + SL intron. Fig. 3 presents the results in the presence (lanes 4 and 6) and the absence (lanes 1 and 3) of Ado-Hcy, respectively. Controls without probe were also included in the reaction (lanes 2 and 5).

All together the data demonstrate that standardization of trans-splicing reaction with $T$. cruzi epimastigote forms (Y strain) permeable cells facilitates the study of RNA processing in these trypanosomatids and can be used as a model of study drug activity on trans-splicing mechanism.

The nitrofuranes are compounds with the capacity to inhibit trypanotiona reductase, an important enzyme involved in the antioxidant metabolism of T. cruzi. With intention to develop more selective drugs, with low toxicity and more specific targets, a reciprocal prodrug of nitrofurazone, the hydroxymethylnitrofurazone (NFOH121), was developed and showed higher trypanocidal activity than nitrofurazone and benznidazol in all stages (Chung 2003). 


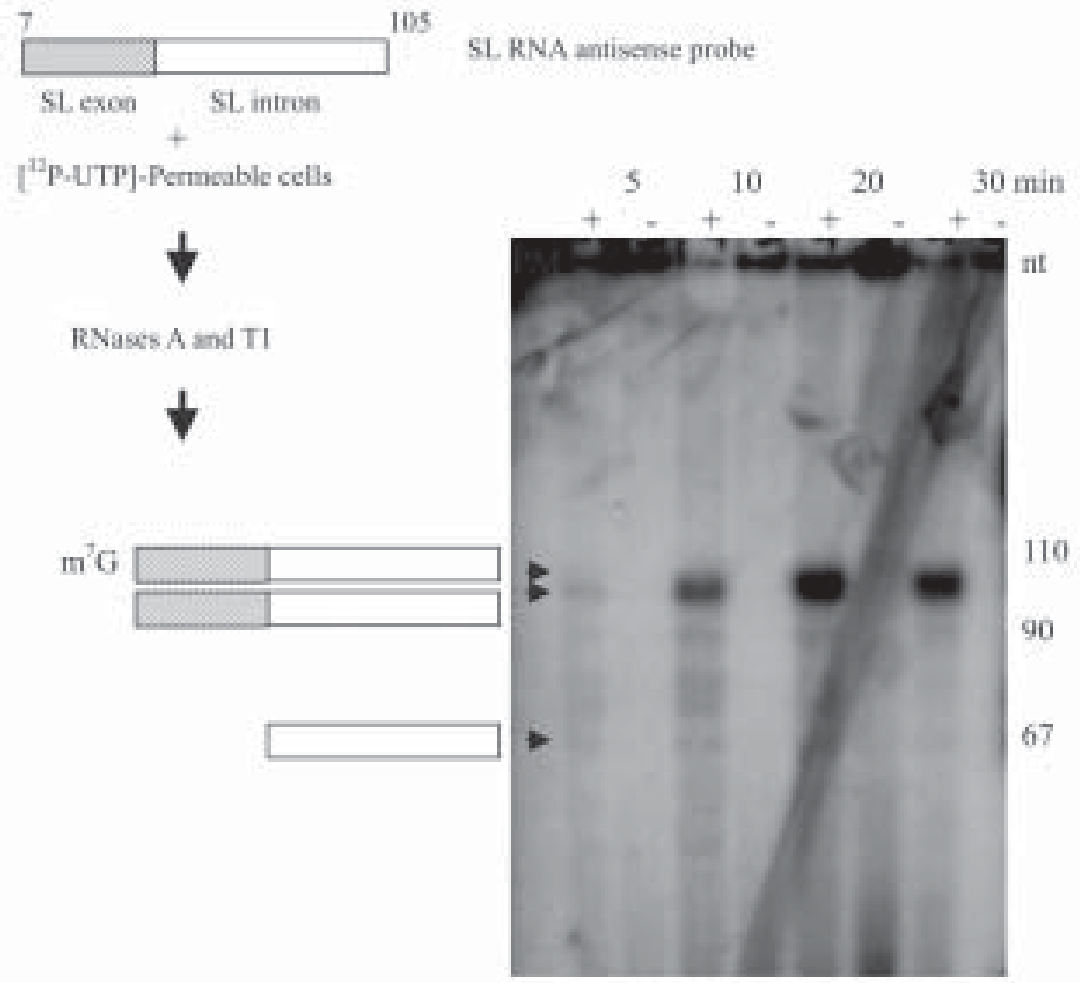

Fig 2: RNAse protection experiments with Trypanosoma cruzi Y strain, electrophoresed on a $10 \%$ polyacrylamide - 7M urea gel and detected by autoradiography. The times of incubation of the reactions are indicated in the figure, in the presence (+) and the absence (-) of SL antisense probe. The bands correspondent to SL exon + SL intron methylated, non-methylated and SL intron are indicated in the figure by the symbols and arrows. The molecular weight in nucleotides (nt) is indicated in the figure; $\mathrm{m}^{7} \mathrm{G}$ : 7-methylguanosine.

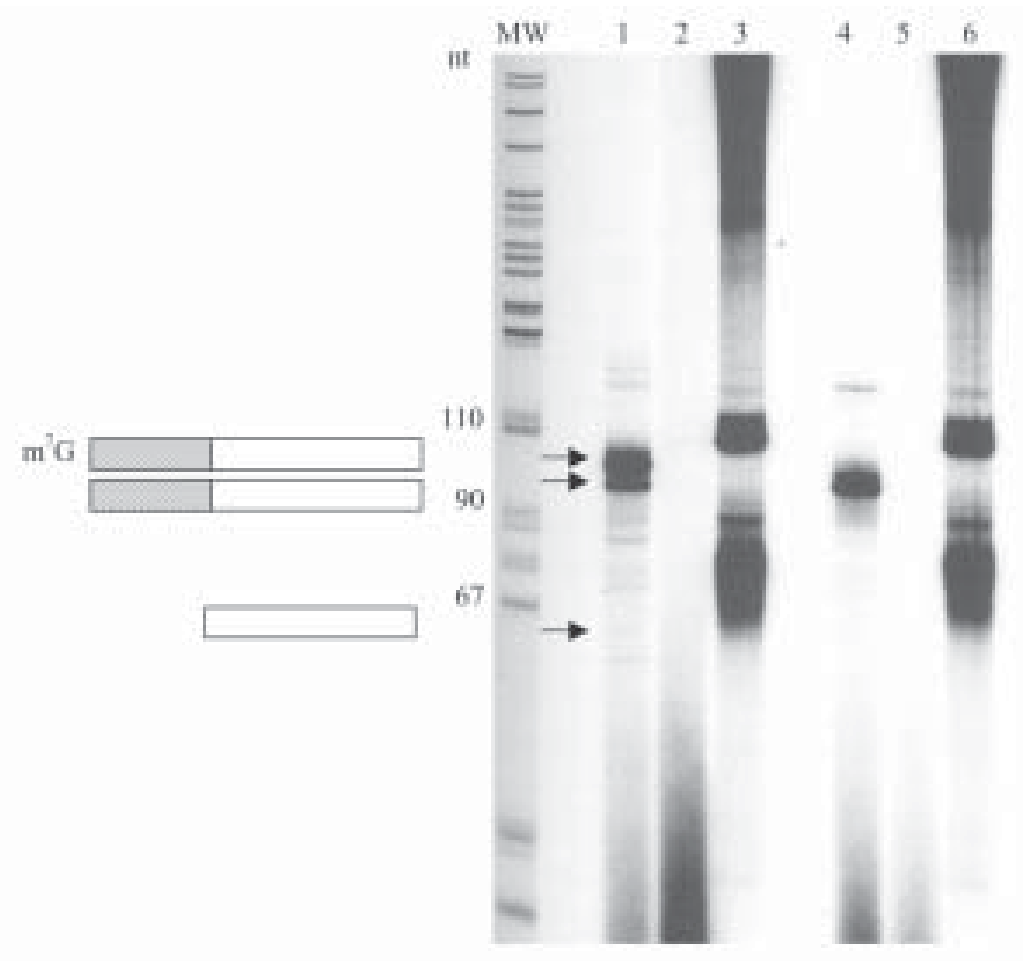

Fig 3: permeable cells and protection with RNases of Trypanosoma cruzi Y strain using S-adenosyl-L-homocysteine (Ado-Hcy). Reaction of permeable cells in the absence (lane 3) and the presence (lane 6) of Ado-Hcy; reaction of protection with RNases in the absence (lane 1) and the presence (lane 4) of Ado-Hcy; RNase controls in the absence of SL antisense probe (lanes 2 and 5). The bands correspondent to SL exon + SL intron methylated, non-methylated and SL intron are indicated in the figure by the symbols. The arrow indicates the referring band to SL exon + SL intron methylated and SL intron (lane 1) and the absence (lane 4). MW: pBR322 digested with MspI labelled with $\left[{ }^{32} \mathrm{P}\right]$-dCTP. $\mathrm{m}^{7} \mathrm{G}$ : 7 -methylguanosine. 


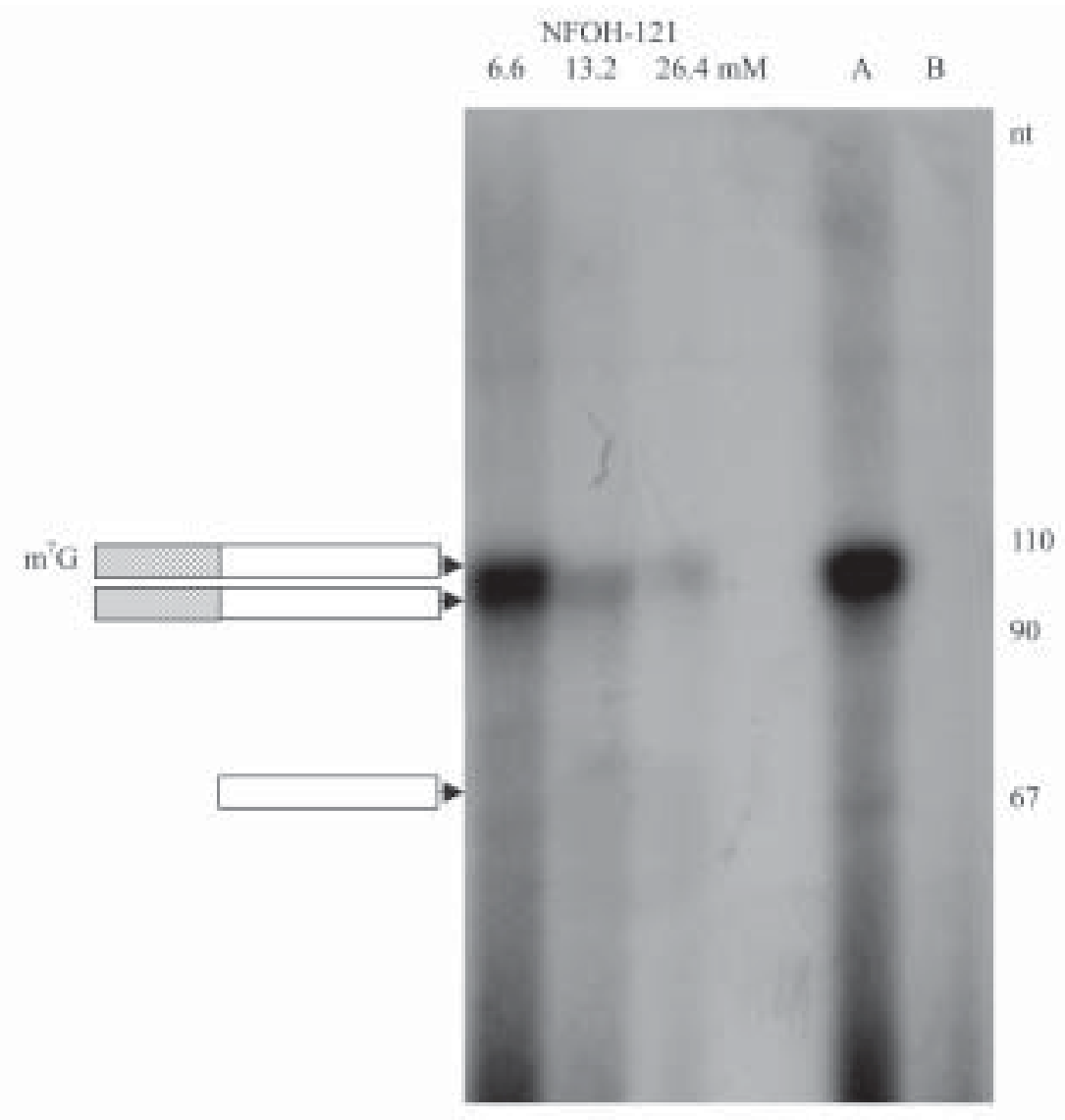

Fig 4: RNase protection reaction with Trypanosoma cruzi $\mathrm{Y}$ strain using NFOH-121 and electrophoresed on a $10 \%$ polyacrylamide - 7M urea gel and detected by autoradiography. The concentrations of NFOH-121 are indicated in the figure. The bands correspondent to SL exon + SL intron methylated, non-methylated and SL intron are indicated in the figure by the symbols and arrows; control with no NFOH121 (A) and RNase control in the absence of SL antisense probe (B) are indicated. The molecular weight in nucleotides (nt) is indicated in the figure; $\mathrm{m}^{7} \mathrm{G}$ : 7 -methylguanosine.

In order to analyse the drug activity in the T. cruzi RNA processing, NFOH-121 (hydroxymethylnitrofurazone) was added to the mixture of reagents in different final concentrations: 6.6, 13.2 and $26.4 \mathrm{mM}$. As shown in Fig. 4, the bands were decreased when higher concentrations were used suggesting that the drug can affect the RNA processing in these parasites. However, the presence of double band (SL RNA methylation) shows that even if the drug interferes in mRNA processing, the transsplicing reaction still occurs. This would mean that the drug activity was prominent at level of the mRNA processing in these parasites and maybe by interfering in the transcription rate. Further studies have been done by the lab in this issue.

\section{ACKNOWLEDGEMENTS}

To Drs C Tschudi and E Ullu from Yale University School of Medicine (New Haven, CT, US) for the support when RMBC was in their lab learning about T. cruzi permeable cells. To Dr Chung Man Chin for provide NFOH-121 (hydroxymethylnitrofurazone).

\section{REFERENCES}

Agabian N 1990. Trans-splicing of nuclear pre-mRNAs. Cell 61: $1157-1160$
Chung MC, Guido RVC, Martinelli TF, Gonçalves MF, Polli MC, Botelho KCA, Varanda EA, Colli W, Miranda MTM, Ferreira EI 2003. Synthesis and in vitro evaluation of potential antichagasic hydroxymethylnitrofurazone (NFOH121): a new nitrofurazone prodrug. Bioorg Med Chem 11: 4779-4783.

Leninger AB, Nelson DL, Cox MM 1995. Princípios de Bioquímica, 2nd ed., Sarvier, São Paulo, p. 644-670.

Mair G, Shi H, Hongjie L, Djikeng A, Aviles HO, Bishop JR, Falcone FH, Gavrilescu C, Santori MMI, Stern LS, Wang Z, Ullu E, Tschudi C 2000. A new twist in trypanosome RNA metabolism: $c i s$-splicing of pre-mRNA. RNA 6: 163169.

Silva LHP, Nussenzweig V 1953. Sobre uma cepa de Trypanosoma cruzi altamente virulenta para o camundongo branco. Fol Clín Biol 20: 191-208.

Ullu E, Tschudi C 1990. Permeable trypanosome cells as a model system for transcription and trans-splicing. Nucl Acids Res 18: 3319-3326.

Ullu E, Tschudi C 1991. Trans-splicing in trypanosomes requires methylation of the 5' end of the spliced leader RNA. Proc Nat Acad Sci USA 88: 10074-10078.

Vianna VF, Ambrósio DL, Cicarelli RMB 2001. Mapeamento de bandas de trans-splicing in vitro com extratos nucleares de Trypanosoma cruzi. Rev Ciên Farm 22: 295-306. 